\title{
Correction to: A traffic light enzyme: acetate binding reversibly switches chlorite dismutase from a red- to a green-colored heme protein
}

\author{
Durga Mahor ${ }^{1}$. Julia Püschmann ${ }^{1}$ - Menno van den Haak ${ }^{1}$ Pepijn J. Kooij ${ }^{1}$ - David L. J. van den Ouden ${ }^{1}$. \\ Marc J. F. Strampraad ${ }^{1} \cdot$ Batoul Srour $^{1,2}$. Peter-Leon Hagedoorn ${ }^{1}$ (i)
}

Published online: 29 May 2020

(c) Society for Biological Inorganic Chemistry (SBIC) 2020

\section{Correction to: \\ JBIC Journal of Biological Inorganic Chemistry (2020) 25:609-620 \\ https://doi.org/10.1007/s00775-020-01784-1}

In the original article published, in the $g_{y}$ value (column) of the $\mathrm{H}_{2} \mathrm{O} / \mathrm{OH}^{-}$species (row) of Table 2 was mistakenly given as " 1.18 " and the correct value is " 2.18 ".
Publisher's Note Springer Nature remains neutral with regard to jurisdictional claims in published maps and institutional affiliations.
Table 2 EPR parameters of AoCld and its complexes

\begin{tabular}{lllllllllllll}
\hline Ligand & & Spin state & $g_{z}$ & $g_{y}$ & $g_{x}$ & ${ }^{\mathrm{a}} W_{z}$ & $W_{y}$ & $W_{x}$ & ${ }^{\mathrm{b}} A_{z}$ & $A_{y}$ & $A_{x}$ & References \\
\hline$-/ \mathrm{H}_{2} \mathrm{O}$ & Narrow & HS & 6.24 & 5.42 & 2.0 & 30 & 40 & 40 & & & {$[4]$} \\
$-/ \mathrm{H}_{2} \mathrm{O}$ & Broad & HS & 6.70 & 5.02 & 2.0 & 27 & 50 & 43 & & & \\
$\mathrm{Ac}^{\mathrm{c}}$ & Major & HS & 5.98 & 5.70 & 1.99 & 27 & 60 & 30 & & & This work \\
& Minor & HS & 6.36 & 5.38 & 1.99 & 15 & 20 & 30 & & & \\
$\mathrm{~F}^{-}$ & & HS & 5.90 & 5.90 & 1.995 & 17 & 17 & 12 & 20 & 20 & 44 & This work \\
$\mathrm{Im}^{\mathrm{d}}$ & & LS & 2.96 & 2.25 & 1.51 & 50 & 50 & 100 & & & {$[4]$} \\
$\mathrm{H}_{2} \mathrm{O} / \mathrm{OH}^{-}$ & High pH & LS & 2.54 & 2.18 & 1.87 & 22 & 15 & 22 & & & {$[4]$} \\
$\mathrm{NO}_{2}^{-}$ & & LS & 2.93 & 2.18 & 1.55 & 25 & 12 & 80 & & & {$[4]$} \\
\hline
\end{tabular}

a Linewidth W in Gauss, ${ }^{\mathrm{b}}$ Hyperfine coupling constant A in Gauss. ${ }^{\mathrm{c}}$ Acetate; ${ }^{\mathrm{d}}$ Imidazole

The original article can be found online at https://doi.org/10.1007/ s00775-020-01784-1.

Peter-Leon Hagedoorn

p.1.hagedoorn@tudelft.nl

1 Department of Biotechnology, Delft University of Technology, Van der Maasweg 9, 2629HZ Delft, The Netherlands

2 Present Address: Institute for Integrative Biology of the Cell (I2BC), CEA, CNRS, Univ. Paris-Sud, Université ParisSaclay, 91198 Gif-sur-Yvette Cedex, France 